\title{
Has strategic planning made a difference to amphibian conservation research in South Africa?
}

\begin{tabular}{|c|c|}
\hline \multicolumn{2}{|c|}{$\begin{array}{l}\text { Authors: } \\
\text { John Measey }{ }^{1} \text { (1) } \\
\text { Jeanne Tarrant }^{2} \text { (D) } \\
\text { Alex Rebelo }^{1,3} \\
\text { Andrew Turner }^{4,5} \\
\text { Louis du Preez }^{2,6} \\
\text { Mohlamatsane Mokhatla }^{1,7} \\
\text { Werner Conradie } \\
\text { Wo }\end{array}$} \\
\hline $\begin{array}{l}\text { Affiliations: } \\
{ }^{1} \text { Centre for In } \\
\text { Department } \\
\text { Zoology, Stell } \\
\text { University, Ste } \\
\text { South Africa }\end{array}$ & $\begin{array}{l}\text { asion Biology, } \\
\text { Botany and } \\
\text { nbosch } \\
\text { lenbosch, }\end{array}$ \\
\hline $\begin{array}{l}{ }^{2} \text { Unit for Envir } \\
\text { Sciences and } \\
\text { North-West U } \\
\text { Potchefstroon }\end{array}$ & $\begin{array}{l}\text { hanmental } \\
\text { hiversity, } \\
\text {, South Africa }\end{array}$ \\
\hline $\begin{array}{l}{ }^{3} \text { Port Elizabet } \\
\text { Humewood, S }\end{array}$ & $\begin{array}{l}\text { Museum, } \\
\text { uth Africa }\end{array}$ \\
\hline $\begin{array}{l}{ }^{4} \text { CapeNature } \\
\text { Services, Stell } \\
\text { South Africa }\end{array}$ & $\begin{array}{l}\text { cientific } \\
\text { nbosch, }\end{array}$ \\
\hline $\begin{array}{l}{ }^{5} \text { Department } \\
\text { and Conserva } \\
\text { University of } \\
\text { Cape, Cape To } \\
\text { South Africa }\end{array}$ & $\begin{array}{l}\text { f Biodiversity } \\
\text { ion Biology, } \\
\text { he Western } \\
\text { wn, }\end{array}$ \\
\hline $\begin{array}{l}{ }^{6} \text { South Africar } \\
\text { Aquatic Biodi } \\
\text { Grahamstown }\end{array}$ & $\begin{array}{l}\text { Institute for } \\
\text { ersity, } \\
\text { South Africa }\end{array}$ \\
\hline $\begin{array}{l}{ }^{7} \text { Rondevlei Sci } \\
\text { South African } \\
\text { Sedgefield, So }\end{array}$ & $\begin{array}{l}\text { entific Services, } \\
\text { Vational Parks, } \\
\text { uth Africa }\end{array}$ \\
\hline $\begin{array}{l}{ }^{8} \text { School of } \mathrm{Na} \\
\text { Management } \\
\text { Mandela Univ } \\
\text { South Africa }\end{array}$ & $\begin{array}{l}\text { ural Resource } \\
\text { Nelson } \\
\text { ersity, George, }\end{array}$ \\
\hline $\begin{array}{l}\text { Correspondin } \\
\text { John Measey, } \\
\text { jmeasey@sun }\end{array}$ & $\begin{array}{l}\text { author: } \\
\text { ac.za }\end{array}$ \\
\hline $\begin{array}{l}\text { Dates: } \\
\text { Received: } 11 \\
\text { Accepted: } 14 \\
\text { Published: } 25\end{array}$ & $\begin{array}{l}\text { ec. } 2018 \\
\text { Mar. } 2019 \\
\text { Sept. } 2019\end{array}$ \\
\hline $\begin{array}{l}\text { Read online: } \\
\text { (1) }\end{array}$ & $\begin{array}{l}\text { Scan this QR } \\
\text { code with your } \\
\text { smart phone or } \\
\text { mobile device } \\
\text { to read online. }\end{array}$ \\
\hline
\end{tabular}

Background: Conservation relies on the strategic use of resources because monies for conservation action are limited, especially in developing countries. South Africa's Frog Atlas project established a baseline for the country's amphibian data and threat levels in 2004, and in 2009 a prioritisation exercise developed a strategy for conservation research.

Objectives: In this article, we assess this strategy for conservation research.

Method: We conducted a quantitative and qualitative assessment of research undertaken since the strategy was developed.

Results: The strategy has produced a lasting impact on taxonomy, ecological studies, monitoring and capacity building. Publications in all areas have increased, but particularly in conservation ecology. Other indicators are increases in the numbers of locality records for target taxa, species descriptions and postgraduate degrees with amphibians as the principal topic. We document important milestones for South African amphibian conservation, including the first Biodiversity Management Plan for Species (BMP-S) for Hyperolius pickersgilli, a smart device app that uploads locality data to an open access database, 15 years of monitoring data and new amphibian identification books for adults and children. The Red List Index calculated for South African amphibians shows that the country's species are becoming more threatened (a 1\% reduction in 10 years), but a hindcasting exercise suggests that most of the damage was already done by 1990 . We provide a checklist for 131 amphibian species in South Africa, of which 82 species are endemic.

Conclusion: A strategy for conservation research was found to greatly augment the focus of research on South African frogs. A new strategy should focus on fewer taxa over meaningful time spans.

Keywords: threatened species; Red List Index; Anura; conservation research; strategy.

\section{Introduction}

The importance of prioritising conservation activities stems from the uneven nature of biodiversity, the irregular spread of threats facing that biodiversity and the inequalities between nations' spending on conservation (Brooks et al. 2006). Developing countries in particular have a strong need to prioritise the limited resources to a very small capacity of conservationists, but often with a higher level of biodiversity. South Africa is a mega-biodiverse region with nine biomes and three recognised biodiversity hotspots (Mittermeier et al. 2004). The country has a strong tradition of strategic conservation planning that continues to the present day, including the active participation of academics (see Rouget et al. 2014 for a recent review). This has included the formation of national and provincial nature reserves, as well as newer conservation agreements entered into with private landowners (e.g. Conradie et al. 2013). Despite this, the basis for conservation planning comes primarily from plant diversity data, although amphibians have also been shown to be moderately represented by the country's protected areas (Drinkrow \& Cherry 1995; Mokhatla et al. 2012). However, large proportions of amphibian species' distributions are outside formal protected areas, thus not contributing to their persistence. This, in part, has led to the high level of threatened status for South Africa's amphibians, with 12.3\% assessed as CR, EN or VU in 2017 (IUCN 2017), and the need to produce a coordinated strategy for their conservation research (Measey 2011).

Amphibians came to the forefront of global vertebrate conservation needs in 1989 at the first World Congress of Herpetology (in Canterbury, UK), when delegates first shared their impressions of declining amphibian populations worldwide (Blaustein \& Wake 1990). This prompted the first

How to cite this article: Measey, J., Tarrant, J., Rebelo, A., Turner, A., Du Preez, L., Mokhatla, M. et al., 2019, 'Has strategic planning made a difference to amphibian conservation research in South Africa?', Bothalia 49(1), a2428. https://doi.org/10.4102/abc.v49i1.2428

Copyright: @ 2019. The Authors. Licensee: AOSIS. This work is licensed under the Creative Commons Attribution License. 
complete Red List assessment for amphibians, which showed more than a third of species to be declining, and the highest proportion of threatened taxa among all the vertebrate groups (Stuart et al. 2004). In South Africa, the same year saw the culmination of a decade-long project to produce the Atlas and Red Data Book of the Frogs of South African, Lesotho and Swaziland (Minter et al. 2004). The project collated data from museum specimens, new field records from participating herpetologists and dedicated fieldwork from the project herpetologists. The 'Frog Atlas' (as it has come to be known) provided a starting point for the region's herpetological community to assess the species in need of research to further their conservation. Furthermore, it has led directly to many national spatial studies that have used the data (e.g. Botts, Erasmus \& Alexander 2011, 2013, 2015; Colville et al. 2014; Mokhatla et al. 2012; Mokhatla, Rödder \& Measey 2015; Schreiner, Rödder \& Measey 2013). However, action plans made during this process (Harrison et al. 2001) seemed to falter without champions to drive the research forward, and a lack of on-the-ground conservation implementation.

In December 2009, the South African National Biodiversity Institute (SANBI) hosted a workshop to re-assess the Red List status of the country's amphibians, and strategise future conservation research in the region. The workshop was broken up into four subject areas: taxonomy, ecology, monitoring and capacity. In each focal subject area, ranking of species provided a framework for amphibian conservation workers in South Africa on which to base future research. In November 2016, SANBI hosted another Red Listing workshop (this time for all southern African amphibians, including Angola). This allowed participants to engage in a retrospective process on the pros and cons of a research strategy, and specifically to ask: has the strategy for amphibian conservation research in South Africa made a difference?

In this article, we ask whether being strategic has made a quantifiable difference to amphibian conservation research in South Africa. To do this, we review the progress made in the conservation of South African amphibians since the 2009 workshop. We provide both qualitative, through the use of case studies and participants' responses at the 2016 workshop, and quantitative information on publications and point locality data, on the utility of a conservation strategy document, and we critique the methodology used to draw up the prioritisation lists. Lastly, we use the Red Listing data produced at the meetings to produce a Red List Index (RLI) (Bubb et al. 2009) for South African amphibians.

\section{Methods and materials}

\section{Strategy workshop in 2009}

The methods used to draw up priority listings were done in the 2009 workshop, and are described by Measey and Tolley (2011a). In summary, conservation research was divided into four main research areas: taxonomy, ecology, monitoring and capacity. Within each of these areas, distinct sub-topics were identified and for each sub-topic each species was given a score of $1-5$, as follows: $1-$ The available information is sufficient.
No priority for further work; 2 - There is limited information, but no priority is assigned; 3 - There are questions, but the priority is low; 4 - Definite questions exist, and a high priority is assigned; 5 - There is an urgent need for immediate work, and the highest priority is assigned. The scores were then summed across all sub-topics to provide a final priority score for each species, together with a list of exactly what should be done. Summed scores were ranked with the species receiving the highest score as the highest priority species. Species that tied on scores were given equal ranks.

\section{Strategy workshop in 2015}

We compared the results of the 2009 prioritisation exercise (Measey 2011) with the achievements made in amphibian conservation research in South Africa. In the qualitative assessment, we considered how the prioritisation exercise had helped in the facilitation of working on conservation of amphibians in South Africa. During the 2015 workshop, participants were encouraged to comment on the efficacy of the strategy following a presentation. Particular emphasis was placed on the ability to leverage funding. We chose to demonstrate how the strategy made tangible differences to research through a series of case studies (Boxes 1 to 4 ), one for each main research area.

The quantitative exercise was conducted using quantities of peer-reviewed scientific papers appearing in Web of Science (www.webofknowledge.com). Two searches were made that encompassed two equivalent time periods prior to and after the December 2009 workshop: 2000-2009 and 2010-2018. For each of these periods, a search was made with the following syntax: TOPIC: 'frog' OR 'anura' OR amphibia* AND ADDRESS: 'South Africa'. The results were first sorted into whether or not the titles showed the publications were focussed on extant amphibians, with those being not applicable being discarded. Next, each paper was sorted into one of the four subject areas covered in Measey (2011), and four additional subject areas that presented themselves during the scoring: disease, parasites, invasions and toxicology. Next, each paper was assessed to determine whether it covered taxa that were prioritised in the 2009 Workshop (see above).

\section{Red List Index for South African amphibians}

The RLI is used as a measure of health for a group of taxa in a specified region (Bubb et al. 2009; Butchart et al. 2007). South Africa is the only country to date to produce such an index for its biodiversity, and this is particularly relevant as far as amphibians are concerned with the three consecutive assessments available for comparison. The RLI uses the change in status for each taxon listed in the IUCN Red List at set time periods in a prescribed formula:

$\mathrm{RLI}_{t}=1-\frac{\sum_{s} W_{c(t, s)}}{W_{\mathrm{EX}} \cdot N}$

[Eqn 1] 
where $W_{c(t, s)}$ is the category $c$ for each amphibian species $s$ at time $t, W_{\mathrm{EX}}$ is for Extinct taxa (none in South Africa) and $N$ is the total number of species assessed (excluding Data Deficient).

The RLI can only be used with taxa that were assessed on all dates, representing $87 \%$ of extant South African amphibian taxa. The remaining $13 \%$ were not assessed as they had not been described or have changed taxonomic designation between Red Listings. We distinguish between assessments that resulted from non-genuine change (either because of improved knowledge of the species [8\%], or because of taxonomic adjustments [1\%]) and those with genuine changes. Non-genuine changes are not included in the RLI.

In a separate exercise, we backcast the status of the 131 extant amphibian species to 1990 using the 1990 national land cover data set (GeoTerraImage 2016), and compared this with the 2017 Red List status. For each species assessed as threatened in 2017, we plotted occurrence records that pre-dated 2000 and current IUCN polygons to determine whether any distributions seemed to have shrunk in the past 17 years. Botts et al. (2013) recorded a number of South African amphibians that seemed to have changed their distribution between two time periods: pre-1996 and 1996-2003. We carefully checked all species that Botts et al. (2013) reported to have changed in distribution, and determined whether reported changes were genuine using new data since 2003. We used land transformation images from 1990 and 2013 (GeoTerraImage 2015) to remove all disturbed areas inside polygons of currently threatened taxa. We examined the changes in transformation for each species and assessed whether any IUCN criteria may have changed between 1990 and 2017. We paid special attention to any likely changes in area of occupancy and/or fragmentation as appropriate for current threatened criteria in each species. We then used our expert knowledge to assess whether there was likely to have been a change in the Red List (using IUCN v3.1) status given changes in the above criteria in 1990. The RLI for all South African amphibians was calculated according to Bubb et al. (2009; see equation 1).

\section{Results and discussion}

Overall, participants were generally positive about the influence of the strategy for conservation research (Measey 2011) on their work. Participants acknowledged that there was a certain level of self-serving in the process that had seen them prioritise species that they were active with in 2009 and had subsequently continued to work with over the subsequent seven years. Despite this, the ranking system used shows no obvious bias, with several species ranked \#1 (in taxonomy, monitoring and capacity) receiving no publications. There has also been a net increase in the amount of material published on South African amphibians, and in particular towards species that were prioritised in the 2009 strategy document (Table 1).

\section{Taxonomy: Understanding and documenting species diversity}

Ten priorities were listed that included 39 species (because of equal rankings). Of these, only seven had received publications that improved their taxonomy by 2018. The highest ranking was Capensibufo rosei (at \#3) that had been recognised as a species complex with three new species described (see Box 1). The lowest ranking was Arthroleptella landdrosia (\#6) from which Arthroleptella kogelbergensis was described by Turner and Channing (2017). Other, non-prioritised, taxa were also described since the workshop, including Cacosternum thorini (see Conradie 2014), Breviceps passmorei and B. carruthersi (see Minter, Netherlands \& Du Preez 2017). Most recently, a previously synonymised species, Arthroleptis wageri, has been resurrected on the basis of molecular evidence (Tolley et al. 2018). Overall, since the 2009 workshop, the number of species in South Africa has grown by 17 (between 2012 and 2018; Figure 1). This represents a $14 \%$ increase, and a major achievement commensurate with the global rate of new amphibian descriptions. In comparison, Köhler et al. (2005) recorded a $26.3 \%$ increase in global descriptions in nearly twice the period (11 years).

Participants in 2016 felt that too many taxonomic issues had been prioritised to be fulfilled in a five-year window. Secondly, that species did not make a good starting point for

TABLE 1: Numbers of publications by authors with South African addresses on amphibians appearing in Web of Science (search made on 05 July 2018 ).

\begin{tabular}{|c|c|c|c|c|}
\hline Subject categories & 2000-2009 & Targeted species & 2010-2018 & Targeted species \\
\hline Taxonomy'† & 32 & 10 & 45 & 11 \\
\hline Conservation and ecology & 16 & 0 & 48 & 26 \\
\hline Monitoring & 0 & 0 & 2 & 0 \\
\hline Education and awareness & 0 & 0 & 2 & 2 \\
\hline Disease & 7 & 1 & 23 & 2 \\
\hline Invasions & 3 & 0 & 22 & 0 \\
\hline Parasitology & 13 & 0 & 27 & 1 \\
\hline Toxicology & 14 & 0 & 7 & 0 \\
\hline N/A & 93 & - & 128 & - \\
\hline Total (without N/A) & 85 & 11 & 176 & 42 \\
\hline South African studies (\%) & 55 & 13 & 50 & 23 \\
\hline
\end{tabular}

Note: Studies without a focus on extant amphibians were considered not applicable (N/A). Subject categories encompass the four strategic chapters in Measey (2011: taxonomy, conservation and ecology, monitoring, education and awareness), and four clear additional categories that emerged during the search (disease, invasions, parasitology and toxicology). Targeted species refer to those that were included in tables (see Measey \& Tolley 2011 for details of methods for inclusion of taxa in tables).

$\dagger$, Taxonomy includes any phylogenetic work, species descriptions and morphology related to taxonomy.

$\$$, Conservation and ecology includes publications on life history information, population genetics or other applicable topics not included in other subject categories 
BOX 1: Capensibufo rosei.

Rose's mountain toadlet, Capensibufo rosei, was one of two species distributed in montane areas of the southwestern Cape of South Africa. The distribution has long been known to be confined to seeps in high altitude areas of the Cape Fold mountains (e.g. De Villiers 2004), and so there has been some suspicion that this taxon represented many cryptic taxa, like other species in this area with similar distributions (e.g. Arthroleptella). Collection of tissues of Capensibufo for a phylogen started in the late 1990s. Tolley et al. (2010) published a phylogeny of mtDNA that was well represented with samples from the $C$ rosei clade. This article showed several well-supported C. tradouwi.

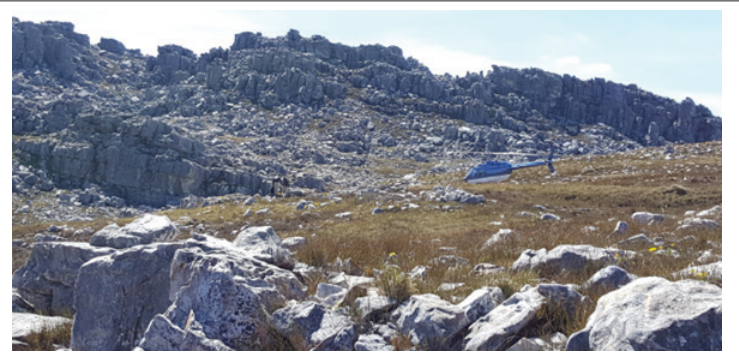

A subsequent publication by Cressy et al. (2015) showed that of all the historical populations known on the Cape peninsula, only one remained with a second found during their study. The article also showed that both of these populations belonged to the same clade, and that this was a distinct species to all other species in the group. However, before any formal conservation assessment could be undertaken, all other species currently within the $C$. rosei group would have to be described and assessed.

The taxonomic work involved capturing new specimens from species that had only been represented by tissue samples in Tolley et al. (2010). This involved many field days, even including charter of a helicopter to reach the upper areas of Du Toits Kloof. Without these specimens, it would not have been possible to describe the species, as each description must be associated with type material. Happily, this was achieved in late 2016 so that the publication describing three new species of Capensibufo appeared in 2017: C. deceptus, C. magistratus and C. selenophos (Channing et al. 2017). It is still known that $C$. tradouwi represents more than one species, and there is an ongoing collection of tissues to complete this phylogenetic work.

Following the publication of Channing et al. (2017), C. rosei (pictured above) was Red Listed as Critically Endangered (SA-FRoG and IUCN 2017). The other new species of Capensibufo are currently listed as Data Deficient, and need to be assessed.

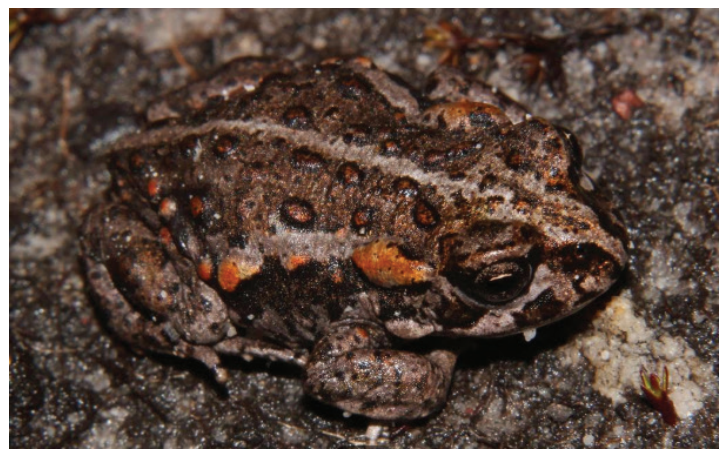

References

Channing, A., Measey, G.J., Villiers, A.L., Turner, A.A. \& Tolley, K.A., 2017, 'Taxonomy of the Capensibufo rosei group (Anura: Bufonidae) from South Africa', Zootaxa 4232(2), 282-292. https://doi.org/10.11646/zootaxa.4232.2.11

Cressey, E.R., Measey, G.J. \& Tolley, K.A., 2015, 'Fading out of view: The enigmatic decline of Rose's mountain toad Capensibufo rosei', Oryx 49(3), 521-528. https://doi. org/10.1017/S0030605313001051

De Villiers, A.L., 2004, 'Capensibufo rosei (Hewitt, 1926)', in L.R. Minter, M. Burger, J.A. Harrison, H.H. Braack, P.J. Bishop \& D. Kloepfer (eds.), Atlas and red data book of the frogs of South Africa, Lesotho and Swaziland, pp. 87-90, Smithsonian Institution, Washington, DC.

Tolley, K.A., De Villiers, A.L., Cherry, M.I. \& Measey, G.J., 2010, 'Isolation and high genetic diversity in dwarf mountain toads (Capensibufo) from South Africa', Biological Journal of the Linnean Society 100(4), 822-834.

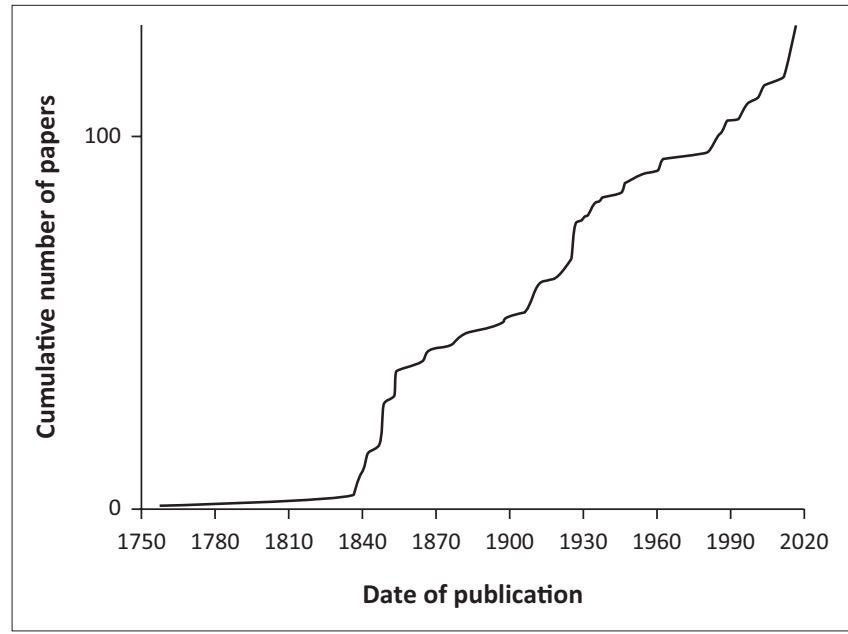

Note that the recent spurt in descriptions (since 2012) is equal to the active period of Hewitt in the 1930s.

FIGURE 1: The cumulative rate of species descriptions for 131 extant taxa in South Africa.

these priorities, and instead these should be genera, with an emphasis being placed on initial phylogenies that attempt to cover the entire distribution as a basis for subsequent taxonomic works. Lastly, the capacity for amphibian taxonomy is low, with 14 out of 17 species in the last six years being described by Alan Channing (Channing 2012; Channing \& Baptista 2013; Channing et al. 2013, 2017;
Turner \& Channing 2017). Only three participants (Channing, Conradie and Minter) currently have the capacity to undertake taxonomic descriptions, and Minter retired in 2010 while Channing retired in 2013 (although his taxonomic works have grown since this time). However, more researchers undertake phylogenies encompassing South African species, including those not based in South Africa. It is noteworthy that South African authors were contributing half of their publications to the taxonomy of species outside of South Africa (mostly on the African continent: Table 1), with only a quarter of taxonomic publications covering species prioritised in 2009.

As demonstrated with the work on C. rosei (Box 1), the starting point for this taxonomic work was a phylogeny, which gave good indication that there were cryptic species. This has been the basis for other work describing new species in the genus Cacosternum (Channing et al. 2013) and Arthroleptella (Turner \& Channing 2017). Participants agreed that phylogenies of genera or larger groups were a good starting point for outstanding taxonomic issues, and agreed that these groups, rather than species, should be targeted in future. For example, the recent phylogeny of the genus Breviceps indicates a number of taxa that are in need of taxonomic descriptions, and will substantially increase the diversity of this group in South Africa (Nielsen et al. 2018). 
Because of the extensive taxonomic revisions in the region over the last 10 years, we take this opportunity to publish a full list of South African amphibian species as an online appendix to this article (https://doi.org/10.6084/m9. figshare.9713978), which will be kept updated as an ongoing list of South African amphibians.

\section{Conservation and ecological studies}

The 2009 prioritisation exercise listed 16 species of South African anurans that qualified for one of four levels of priority for conservation and ecological studies.

The most basic information needed in understanding most amphibian species in South Africa is an increase in the knowledge of their distribution. The number of new locality points is especially large for species that have received a lot of attention. The Western Leopard Toad, Sclerophrys pantherina, has been the subject of a powerful Citizen Science campaign that has helped to document its distribution in detail (Figure 2a). This species lends itself to this type of data collection as it is a charismatic and easily observed species within an urban area (Measey, Dorse \& Faraday 2012). The Kloof Frog, Natalobatrachus bonebergi, is monitored regularly by volunteer groups, allowing additional localities to be registered (Figure 2b; Table 2). Lastly, the Knysna Leaffolding Frog, Afrixalus knysnae, is the subject of a student project that aims to document all extant localities in the range (Figure 2c). Most of the species prioritised in 2009 show a similar trend to these examples.

Although not immediately obvious in the data, this period also saw the important rediscovery of Vandijkophrynus amatolicus (see Tarrant \& Cunningham 2011). In 2009, there was concern that this species was possibly extinct (Conradie \& Tarrant 2011), but following dedicated annual searches,
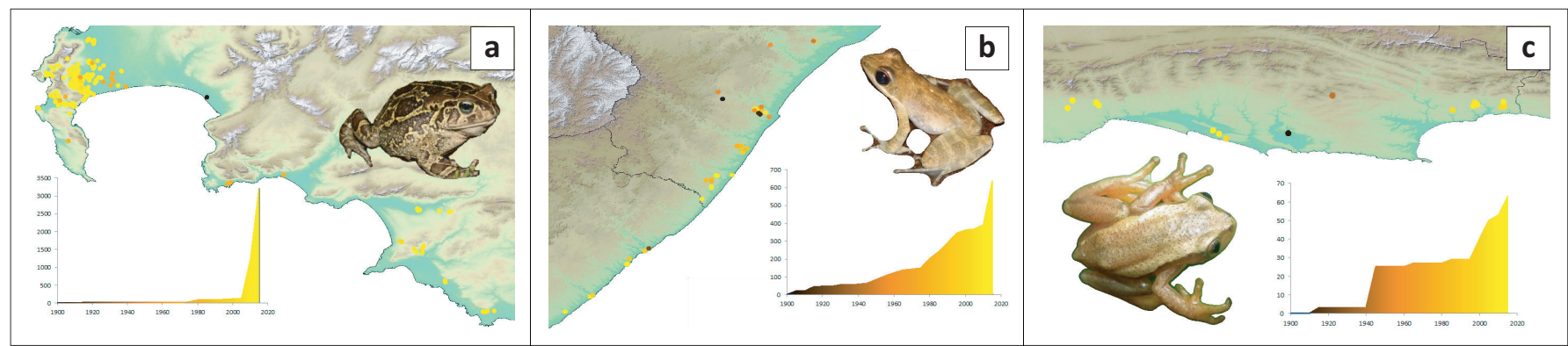

Note that cumulative numbers of distribution points are shown with different scales on the $y$-axis. Records without locations accurate to minutes are not presented.

FIGURE 2: Amphibian records for many species prioritised in the 2011 strategy have increased. Most species show a sudden increase in records since 2000 , after the Frog Atlas project finished. Some species, for example, Sclerophrys pantherina (panel a), have the bulk of their records acquired through Citizen Science, while others (e.g. Natalobatrachus bonebergi: panel b) were the subject of student projects and then monitoring studies. Student projects continue to play an important role in producing distribution data, as shown here with Afrixalus knysnae (panel c, photo by Colin Ralston). Each graph shows data points within the range of species from 1900 (black) shaded through to the present day (yellow - most recent points are plotted over older points).

TABLE 2a: Amphibian monitoring projects in South Africa with approximate location and monitoring method.

\begin{tabular}{|c|c|c|c|c|c|c|}
\hline Priority & Species & Life history stage & Methodology & Data since & Frequency & Person or institution \\
\hline 1 & Hyperolius pickersgilli & A & Acoustic, CMR & 2012 & Annual & Tarrant, EWT \\
\hline 2 & Capensibufo rosei & A & CMR - batch; Genetic monitoring & 2007 & Annual & Tolley, Measey \\
\hline 2 & Afrixalus knysnae & A & Acoustic; Modelling and ground-truthing & 2016 & Monthly & De Lange, Du Preez, NWU \\
\hline 3 & Vandijkophrynus amatolicus & A & Acoustic; Active searching; Pit-fall traps & 2014 & Annual & Tarrant, EWT \\
\hline 4 & Natalobatrachus bonebergi & E & Clutch counts & 2013 & Monthly & EWT, KZN Wildlife, ECPTA \\
\hline 5 & Leptopelis xenodactylus & A & Acoustic (automated) & $\begin{array}{l}2016 \\
2018\end{array}$ & Annual & $\begin{array}{l}\text { KZN Wildlife, EWT } \\
\text { NWU }\end{array}$ \\
\hline 5 & Breviceps sylvestris & - & - & - & - & Not monitored \\
\hline 6 & Heleophryne rosei & $T$ & Area counts & 1995 & Annual & CapeNature \\
\hline 7 & Sclerophrys pantherina & A & Dorsal photos; Genetic monitoring & 2010 & Annual & WLT-CC \\
\hline 7 & Arthroleptella rugosa & A & Aural & 2002 & Annual & CapeNature \\
\hline 8 & Hemisus guttatus & - & - & - & - & Not monitored \\
\hline 8 & Heleophryne hewitti & T/A & Tadpole counts; Acoustic & 1998 & Annual & PEM, ECPTA, Cape Pine \\
\hline 8 & Afrixalus spinifrons & - & - & - & - & Not monitored \\
\hline 8 & Microbatrachella capensis & A & Aural & 1995 & Annual & CapeNature \\
\hline 9 & Anhydrophryne ngongoniensis & A & Acoustic & 2008 & Annual & Harvey, Tarrant \\
\hline 10 & Breviceps macrops & A & Photo & 2002 & Annual & Channing \\
\hline 10 & Arthroleptella subvoce & A & Aural & 2008 & Annual & CapeNature \\
\hline 10 & Cacosternum capense & - & - & - & - & Not monitored \\
\hline N/A & Amietia hymenopus & $A / T$ & Count of adults & 2008 & Annual & Du Preez, Weldon \\
\hline N/A & Arthroleptella lightfooti & $\mathrm{A}$ & aSCR & 2016 & Annual & Measey \\
\hline
\end{tabular}

Note: Life history stage is divided into adults (A) and tadpoles (T). Methodologies include capture-mark-recapture (CMR), acoustic spatial capture recapture (aSCR), and passive integrated transponders (PIT) tags. Priority listed is from Measey et al. (2011). Institutions are listed only if the monitoring is likely to continue after the current people responsible have retired.

EWT, Endangered Wildlife Trust; NWU, North-West University; ECPTA, Eastern Cape Parks \& Tourism Agency; WLT-CC, Western Leopard Toad Conservation Committee; PEM, Port Elizabeth Museum. 
TABLE 2b: Amphibian communities monitored.

\begin{tabular}{lllllll}
\hline Priority & Species & Life history stage & Methodology & Data since & Frequency & Person or institution \\
\hline N/A & Ndumu NR & A/T & Acoustic & 2017 & Annual & Du Preez \\
N/A & Nottingham Road & A/T & Acoustic & 2014 & Annual \\
N/A & Landdroskop & A & Aural & 2002 & Annual & CapeNature \\
N/A & Groot Winterhoek & A & Aural & 2008 & Annual & CapeNature \\
N/A & Swartboskloof & A & Aural & 2002 & Annual & CapeNature \\
N/A & Mont-aux-Sources & A/T & Count of adults & 2008 & Annual & Weldon NWU \\
\hline
\end{tabular}

Note: Life history stage is divided into adults (A) and tadpoles (T). Methodologies include capture-mark-recapture (CMR), acoustic spatial capture recapture (aSCR), and passive integrated transponders (PIT) tags. Priority listed is from Measey et al. (2011). Institutions are listed only if the monitoring is likely to continue after the current people responsible have retired. NWU, NorthWest University.

BOX 2: A Biodiversity Management Plan for Species for Hyperolius pickersgilli.

A Biodiversity Management Plan for Pickersgill's Reed Frog, Hyperolius pickersgilli, was promulgated in June 2017 (Armstrong \& Tarrant 2017). This was a crucial and coordinated effort towards conserving this Endangered species, found at only 25 sites (as of February 2018), in highly fragmented coastal wetland habitat of KwaZulu-Natal. The species had been prioritised for conservation action because of its Red List status, endemism and ongoing deterioration in and loss of habitat (Measey 2011)

Threats facing the species include:

- Habitat loss as a result of wetland drainage or destruction for agricultural, urban and industrial development.

- Severe habitat fragmentation and small, isolated sub-populations.

- Invasion of alien vegetation and afforestation resulting in drying out of breeding sites.

- Pollution from pesticides and other contaminants.

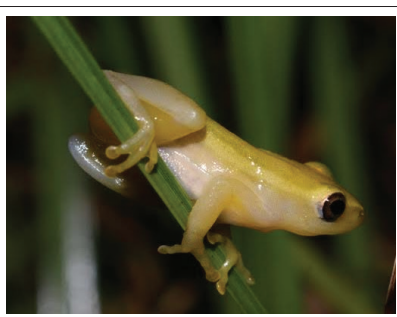

A Biodiversity Management Plan for Species (BMP-S) provides an action plan for multiple stakeholders needed to address the key threats facing a severely threatened species, and ultimately, the assured persistence of Pickersgill's Reed Frog. In terms of legislation, Section 9 of the National Environmental Management: Biodiversity Act, 2004 (Act No. 10 of 2004) (NEMBA) provides for the issuing of national norms and standards for the management and conservation of South Africa's biodiversity and its components. The possibility of a BMP-S for this species was first discussed in 2009. The Endangered Wildlife Trust (EWT) and Ezemvelo KZN Wildlife worked together to initiate the BMP-S process with the Department of Environmental Affairs, and are now actively implementing the interventions laid out in the plan, including strengthening partnerships, improved knowledge of the species itself and the discovery of new sub-populations, resulting in the species being down-listed from Critically Endangered to Endangered in 2016.

Using the Pickersgill's Reed Frog as a flagship species to prioritise the wetland areas in which it is found, the BMP-S allows for improved management and protection efforts of this habitat, which itself is Critically Endangered Indian Ocean Coastal belt Wetland. Many of these wetlands fall within the National Freshwater Ecosystem Priority Areas (NFEPAs), which also made use of Wetland. Many of these wetlands fall within the National Freshwater Ecosystem Priority Areas (NFEPAs), which also made use of
occurrences of threatened frog species to prioritise wetlands. As a result of lack of management, most of the sites at which this special frog species occurs are in an ongoing state of degradation and require implementation of management practices, including:

- Removal of alien invasive vegetation and the prevention of new pioneer invasions.

- Holistic catchment management.

- Improved wetland buffer-zone management.

- Implementation of species monitoring at selected sites.

- Wetland rehabilitation.

- An active captive breeding programme.

- Formal habitat protection of additional sites.

\section{References}

Armstrong, A.J. \& Tarrant, J., 2017, 'Biodiversity management plan for Hyperolius pickersgilli', National Department of Environmental Affairs, National Environmental Management: Biodiversity Act 10 of 2004, Government Notice No. 423 in Government Gazette 40883 of 20 June 2017, Government of South Africa, Pretoria.

Measey, G.J., 2011, Ensuring a future for South Africa's frogs: A strategy for conservation research, SANBI Biodiversity Series, SANBI, Pretoria.

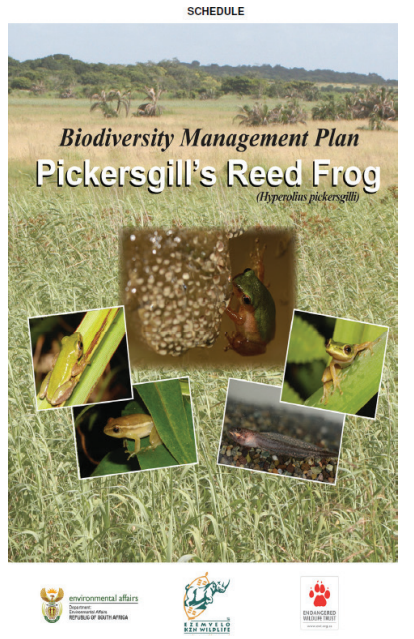

including through the use of a predictive ecological niche model based on habitat suitability, and a project, nine new records exist in the current period, which is a doubling of those found during the Frog Atlas. The species remains, however, Critically Endangered because of its extremely restricted range, ongoing threats and no formal protection within its range.

The period has also seen 48 articles being published on subjects touching on the conservation and ecology of South African frogs, including 25 on taxa that were prioritised in 2009. Noteworthy are the important insights into the life history and conservation of $C$. rosei on the Cape Peninsula (Becker et al. 2018; Cressey, Measey \& Tolley 2015; Da Silva et al. 2016; Da Silva \& Tolley 2018; Edwards, Tolley \& Measey 2017), which was listed with the highest priority (Measey, Minter \& Turner 2011), seven publications on Xenopus gilli, listed at priority level 4 (Conlon et al. 2015; De Villiers et al.
2016; Fogell, Tolley \& Measey 2013; Furman et al. 2017; Measey \& De Villiers 2011; Thorp, Vonesh \& Measey 2019; Vogt et al. 2017), as well as publications on Hyperolius pickersgilli (see Tarrant \& Armstrong 2013) and S. pantherina (see Da Silva et al. 2017; Measey \& Tolley 2011b).

The strategy document highlighted the possibility of using Biodiversity Management Plans for Species (BMP-S) as a means of bringing together large numbers of stakeholders into an agreed conservation framework (NEMBA 2009). The announcement in 2017 that a BMP-S had been promulgated for H. pickersgilli (see Armstrong \& Tarrant 2017) is especially important for the long-term conservation of this species, and the first of its kind in South Africa (see Box 2).

While BMP-S are one solution for large numbers of stakeholders, other species are better handled with action plans that involve fewer stakeholders. This is the approach 
being taken with the Critically Endangered Table Mountain Ghost Frog, Heleophryne rosei, which has now been granted Table Mountain Fund funding for a project to carry out priorities outlined in an action plan over the coming five years.

Despite the great success in terms of locality records, conservation policy and publications, it was felt by the participants that five years was too short a time frame for most ecological studies. The publications that exist are not representative of all the studies that have taken place during the period as many studies are not yet finished. Secondly, like the need for a better focus in taxonomy, the participants felt that a shorter list of priority species would be better served by the academic community.

\section{Assessing status and trends}

The 2009 exercise listed 20 South African amphibian species across ten priority approaches that required monitoring. In the ten years following this meeting, two new species have been added to the list of monitored species (Table 2). However, three are not monitored at all, and two have not been maintained on an annual basis, and this is cause for concern. Monitoring takes place using very different methodologies in different areas, but many monitoring exercises are plagued by methodological inconsistencies and especially the lack of repeated measures that would allow for estimation of variance together with the estimate of quantity. However, new methodologies for monitoring are becoming available, especially through recording of calling individuals using microphone arrays (see Box 3 ).

The strategic importance of monitoring methodology is important when considering the cost of acquiring long-term data sets. For example, larvae of $H$. rosei are monitored annually by counting tadpoles within a $10 \mathrm{~m}$ stretch of set streams coming off Table Mountain. However, the stochastic fluctuations in the data gained from this monitoring make it of little use other than to gauge presence or absence in each stream. The need for an improved methodology was recognised in the 2016 meeting, and a focus group is now working towards an action plan for the species that will involve quantitative estimates of larval abundance through capture-mark-recapture (CMR) protocols, which are particularly strong for quantitative monitoring protocols. Becker et al. (2018) used CMR data on C. rosei to determine some unusual life history parameters of this species. Even though this monitoring exercise only involved a yearly batch mark, the authors were able to discover an inverse relationship between breeding period rainfall and survival. De Villiers and Measey (2017) also used CMR on the overland dispersal of Xenopus laevis over two years in a population in Kleinmond.

Although not present in the strategy document, some studies of genetic monitoring have appeared (Da Silva \& Tolley 2018; Furman et al. 2017) where tissue samples stored over time have been made use of. These publications provide important information about the long-term genetic health of populations, and demonstrate the importance of facilities that curate and maintain genetic samples.

Success of monitoring can really only be gauged on a longterm basis, and so we assembled a list of amphibian species that are currently monitored in South Africa together with the methodologies (Table 2). Many species do not have consistently complete data sets and rely on individuals rather than institutions. Both Ezemvelo KwaZulu-Natal Wildlife and CapeNature have embraced amphibian monitoring at an institutional level (see Box 3), but it is important that methodology is improved to deliver quantitative repeatable measures.

While monitoring is needed to assess population trends, some anuran species still lack basic distribution data. These species may be scarce during non-breeding conditions (e.g. Cacosternum capense), recently described (e.g. Cacosternum nanogularum) or simply be far away from professional herpetologists (e.g. Strongylopus springbokensis) and may require dedicated surveys in these areas or targeted searches during the breeding season, as is being done for H. pickersgilli, Leptopelis xenodactylus and A. knysnae.

\section{Education, awareness and capacity building}

The 2009 assessment highlighted the acute shortage of capacity in South Africa's institutional and academic amphibian conservationists. At the time, South Africa had 14 people employed and working at least part time on amphibian conservation (Tolley et al. 2011). Today, this has reduced to nine, mostly as a result of retirement and a lack of replacement with amphibian-focussed workers (see Table 3).

Although the situation looks bleak, there have been a considerable number of postgraduate students who have conducted their MSc or PhD studies on amphibians (Table 4).

Publishing has seen great advances with another edition of the popular field guide (Du Preez \& Carruthers 2017), a revision of the popular Frogs and Frogging (Carruthers \& Du Preez 2011a), the release of Afrikaans version Paddas and Paddajolyt (Carruthers \& Du Preez 2011b), the first field guide in an ethnic African language, namely, A Bilingual Field Guide to the Frogs of Zululand (Phaka et al. 2017), a guide to the tadpoles of Africa (Channing, Rödel \& Channing 2012), the publication of a book for children My First Book of South African Frogs (Tarrant 2015), including a smart device application, and a field guide to the amphibians of Africa (Channing \& Rödel 2019).

The view of amphibians in South Africa is extremely varied (Tarrant, Kruger \& Du Preez 2016), and popular publications are perhaps the most important contribution to capacity building in South Africa as they will help contribute to Citizen Science, and the latter to future Citizen Scientists as well as potential students and career herpetologists. 
BOX 3: Monitoring of Arthroleptella rugosa.

The Critically Endangered Rough Moss Frog, Arthroleptella rugosa, is restricted to the southern slopes of a single, small, isolated mountain threatened by invasive alien plants and too frequent fires. Fortunately, a large proportion of this land is part of the Klein Swartberg Conservancy - a voluntary association of landowners and managers that supports conservation while allowing farming.

The total population of frogs was initially estimated at only 400 individuals spurring CapeNature to establish a long-term population monitoring programme. Counts were made by observers listening to calling male frogs and assigning call counts to were made by observers listening to calling male frogs and assigning call counts to et al. 2009). The data collected due to a fire, swept through the area in 2012, has shown that the populations decline dramatically. A Manual Calling Survey has several drawbacks as the calls do not have particularly fine resolution, are very several drawbacks as the calls do not have particularly fine resolution, are very dependent on the observer's experience and give only single point estimations of numbers with no way of calculating the area listened to, or error around each estimate.

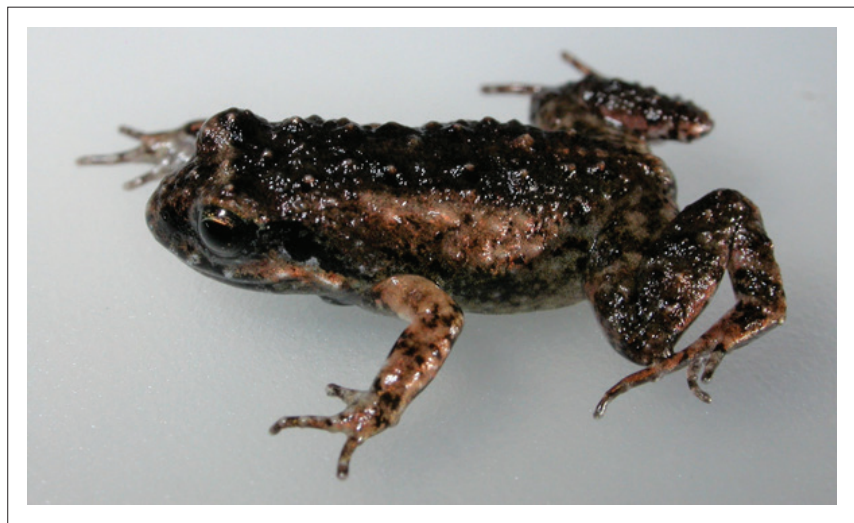

FIGURE 1-B3: The Rough Moss Frog, Arthroleptella rugosa.

Three years after the fire, in winter 2015, application of acoustic spatial capture-recapture (aSCR) methods (see Stevenson et al. 2015) to call data recorded on an array of six microphones allowed improved estimations of frog density. The Stark et al. (in press) study recorded the density of calling males across 2.74 ha (in seven acoustic surveys) of a total estimated occupied area 5.15 ha across the Klein Swartberg Mountain, estimating a total population size of 2060 calling males individuals ( \pm 132.2 with $95 \%$ Cl; Stark et al. in press).

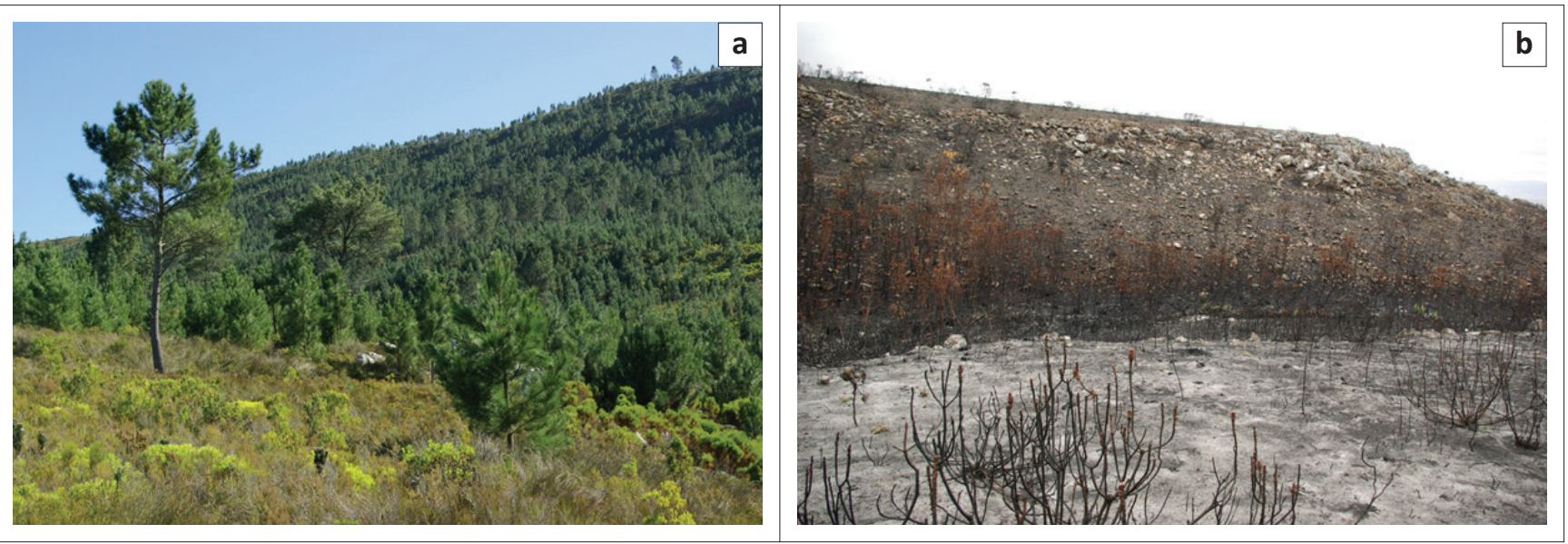

FIGURE 2-B3: The Klein Swartberg is adversely affected by (a) invasive alien trees before and (b) after extreme fires in January 2012.

Fire is important in this system and the Klein Swartberg Mountain is heavily invaded by invasive woody plants, particularly Mediterranean cluster pines (Pinus pinaster), which provide much more fuel than the indigenous vegetation. Active fire management is required to control fuel loads and keep fire return intervals well spaced to allow for frog population recovery.

\section{References}

Dorcas, M.E., Price, S.J., Walls, S.C. \& Barichivich, W.J., 2009, 'Auditory monitoring of anuran populations', in C.K. Dodd (ed.), Amphibian ecology and conservation: A hand book of techniques (pp. 281-298), Oxford University Press, Oxford.

Stark, D., Turner, A., Van Rensburg, B.J. \& Measey, J., in press, 'Population estimation of a cryptic moss frog using acoustic spatially explicit capture recapture', in S.C. Walls \& K.M. O'Donnell (eds.), Strategies for conservation success in herpetology, Herpetological conservation series, vol. 4, Society for the Study of Amphibians and Reptiles, St. Louis, MO.

Stevenson, B.C., Borchers, D.L., Altwegg, R., Swift, R.J., Gillespie, D.M. \& Measey, G.J., 2015, 'A general framework for animal density estimation from acoustic detections across a fixed microphone array', Methods in Ecology and Evolution 6(1), 38-48.

TABLE 3: People in jobs where they contribute to amphibian conservation.

\begin{tabular}{lccccc}
\hline Job type & Provincial conservationist & Academics & Museum workers & Independent workers & NGOs \\
\hline 2009 & 3 & 8 & 2 & 1 & 1 \\
2018 & 2 & 4 & 1 & 1 & 9 \\
\hline
\end{tabular}

NGOs, non-governmental organisations.

Of particular note is the publishing of an app version of Du Preez and Carruthers (2017) that can be installed on cell phones or tablets, and thus is portable for the field (see Box 4). Similarly, other initiatives such as iNaturalist (https://www.inaturalist.org/places/south-africa) that took on all data from iSpot in 2017 and the Animal Demography Unit's FrogMap (http://vmus.adu.org.za/) have accumulated over 6500 observations. These projects are clearly important contributions to amphibian distribution data, and have the support of the professional amphibian community. Indeed, the addition of these data made an important contribution to the 2016 Red List reassessment. However, the data have the same types of bias found in the Frog Atlas data (Botts et al. 2011), and provided little input on species that had no active work on them. Thus, at least in South Africa, this kind of Citizen Science will not replace dedicated and targeted fieldwork on amphibians. 
TABLE 4: MSc and PhD students who have graduated with theses on amphibians in South Africa since 2009.

\begin{tabular}{ll}
\hline Degree & Surname (year graduated, degree awarding institution) \\
\hline MSc & Becker (2017, UCT), Bell (2009, UWC), Botha (2014, NWU), Brown (2015, \\
& NWU), Coetzee (2018, NWU), Cressy (2012, UCT), De Villiers (2016, SU), \\
& Doucette-Riise (2012, UCT), Du Pisanie (2015, NWU), Du Preez (2018, \\
& NWU), Kruger (2011, NWU), Kruger (2017, NWU), Kushata (2018, SU), Le \\
& Roux (2011, NWU), Louw (2018, SU), Meyer (2009, NWU), Mokhatla \\
& (2012, UP), Phaka (2018, NWU), Rebelo (2016, SU), Ryan (2015, Wits), \\
& Telford (2015, UWC), Thorp (2016, SU), Trenor (2016, NWU), Viviers \\
& (2013, NWU), Wilson (2015, UWC), Zaayman (2013, NWU). \\
PhD & Botts (2013, Wits), Davies (2015, SU), Kruger (2014 NWU), Minter (2014, \\
& Wits), Mokhatla (2018, SU), Tarrant (2012 NWU), Turner (2009, UWC), \\
& Vimercati (2017, SU), Yetman (2015, UP).
\end{tabular}

NWU, North-West University; SU, Stellenbosch University; UP, University of Pretoria; UCT, University of Cape Town; UWC, University of the Western Cape; Wits, University of the Witwatersrand. See reference list for details of theses and links to libraries in which they are deposited.

\section{Red List Index for South African amphibians}

The RLI for 1990 was 0.9017, higher than during any IUCN assessment, while in 2017 it was 0.8917 , a reduction of $1 \%$ in RLI. The change in RLI was attributed to the deteriorating of Red List status of six endemic frogs, all through habitat loss and degradation (Table 5). It is noteworthy that there has been no amelioration of threatened status for any species within this period.

While gross changes in published assessments (Table 5: RLI*) appear to have an improving index, this is because of non-genuine changes in assessments either because of

BOX 4: Contributions to amphibian Citizen Science through the frog app.

Traditionally, identification of amphibians in southern Africa has been made by professionals using available keys, and by the public through popular field guides. Books on frogs in the region include narrative accounts on the natural history of species (e.g. Rose 1962; Wager 1965), to the first field guides that continued the narrative, but included information on the identity of all known species (e.g. Channing 2001; Passmore \& Carruthers 1979). In the last ten years or so, enthusiasts have been able to contribute records of species that they find to online databases, and these records can then be used by scientists to aid them in conservation tasks such as Red Listing (see text). Such contributions have been widely termed Citizen Science, and conservationists have been quick to realise the potential benefits from Citizen Scientists to contributing more data than can be gathered by researchers and conservation agencies.

The publication of Du Preez and Carruthers (2009) extended the scope of this popular field guide to the whole of southern Africa. The update (Du Preez \& Carruthers 2017) was published alongside an electronic version of the entire book. Parallel to this an app for use on smart phones and tablets was developed that covers 161 species from southern Africa with more than 600 photographs showing colour variation. It involves some smart ways to overcome the difficulties the layman might experience in identifying frogs:

- The 'Find me' GPS feature automatically lists only those species that occur in that area. This can be used off line to indicate a locality that has been visited or that will be visited.

- Four simple choices: The shape of the eye, the toe tips, the webbing and the digging heel - further shorten the list of possible options.

Each species page contains relevant text for the species, key ID points, a distribution map, the call and for selected species a short video clip. A 'compare' function allows you to view two different frog species side by side. It also allows for the upload of images and metadata to the ADU's Frog Map project (http://frogmap.adu.org.za/). One additional advantage of the app format is that it can be updated more frequently than printed matter, quickly including newly described species (see text).

This app allows for direct contributions by Citizen Scientists to conservation efforts, and has a great potential to considerably increase and improve the data that amphibian conservationists have to use in the future.

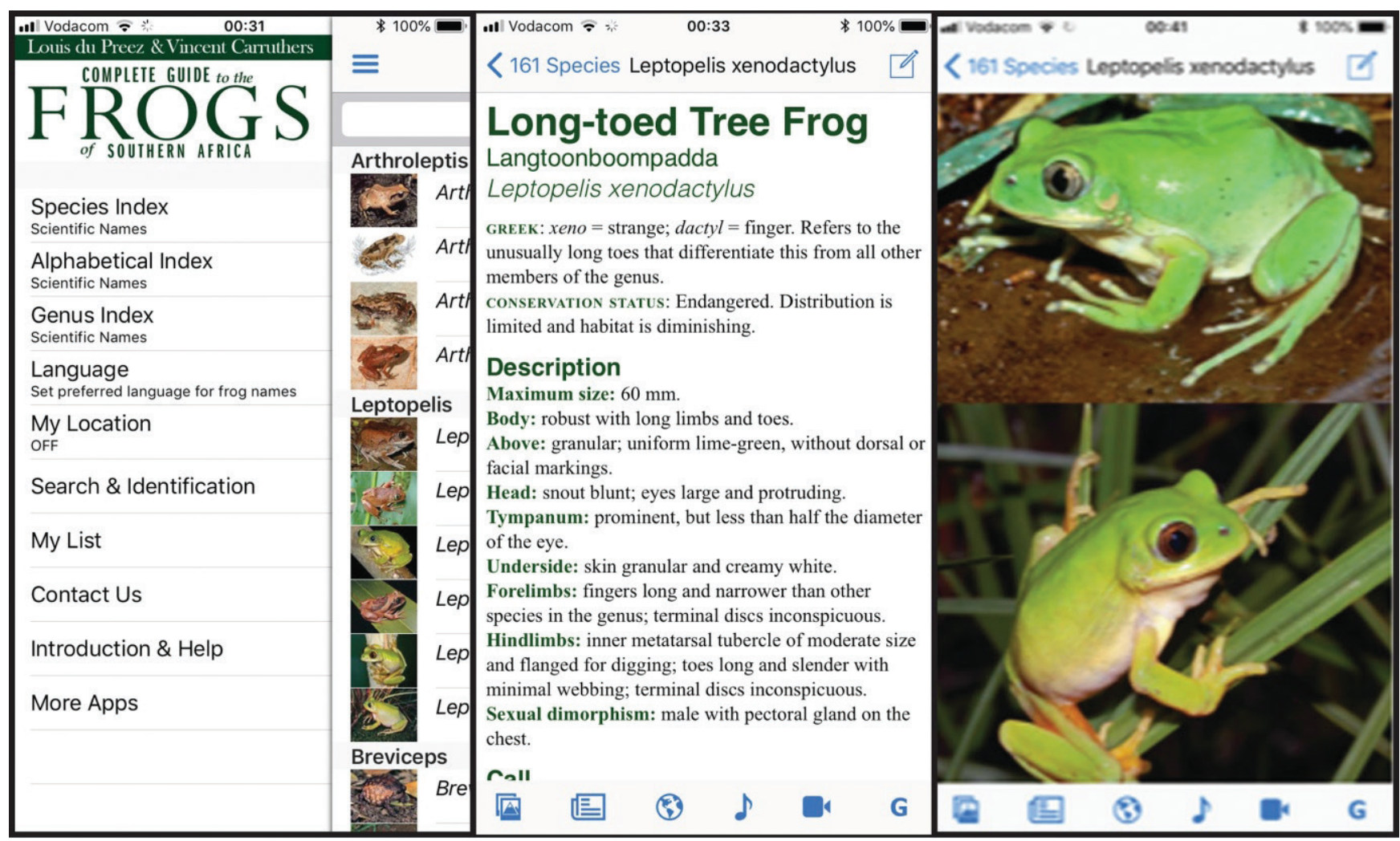

References

Channing, A., 2001, Amphibians of central and southern Africa, Comstock Pub. Associates, Ithaca, NY.

Du Preez, L.H. \& Carruthers, V.C., 2009, Frogs of Southern Africa: A complete guide, Struik Nature, Cape Town.

Du Preez, L.H. \& Carruthers, V.C., 2017, Frogs of Southern Africa: A complete guide, Penguin Random House, Cape Town.

Rose, W., 1962, The reptiles and amphibians of Southern Africa, Maskew Miller, Cape Town.

Passmore, N.I. \& Carruthers, V.C., 1979, South African frogs, p. 270, Witwatersrand University Press, Johannesberg.

Wager, V.A., 1965, The frogs of South Africa, Purnell, Cape Town. 
TABLE 5: The Red List Index of 113 South African amphibians assessed in three periods.

\begin{tabular}{lccc}
\hline Year & $\mathbf{2 0 1 5}$ & $\mathbf{2 0 0 9}$ & $\mathbf{2 0 0 4}$ \\
\hline RLI adjusted & 0.890265 & 0.892035 & 0.892035 \\
RLI* & 0.891667 & 0.883186 & 0.881905 \\
\hline
\end{tabular}

RLI, Red List Index.

*, Note that without adjustment the RLI is not considered accurate as it includes non-genuine change in assessments because of improved knowledge or taxonomic change.

TABLE 6: Details of South African amphibians that we inferred had changed their Red List $\uparrow$ status between 1990 and 2017 because of habitat loss.

\begin{tabular}{llll}
\hline Species & 2017 RL Criteria & 1990 & $\mathbf{2 0 1 7}$ \\
\hline Afrixalus knysnae & B1ab(i,ii,iii,v)+2ab(i,ii,iii,v) & VU & EN \\
Amietia hymenopus & - & LC & NT \\
Anhydrophryne ngongoniensis & B1ab(i,ii,iii,iv)+2ab(i,ii,iii,iv) & VU & EN \\
Hemisus guttatus & - & LC & NT \\
Vandijkophrynus amatolicus & B1ab(i,ii,iii) & EN & CR \\
Xenopus gilli & B1ab(ii,iii, $)+2 a b(i i, i i i, v)$ & VU & EN \\
\hline
\end{tabular}

$\dagger$ Red List categories abbreviated are LC (Least Concern), NT (Near Threatened), VU (Vulnerable), EN (Endangered) and CR (Critically Endangered). See IUCN (2017) for more information on these categories and the corresponding Red List Criteria.

improved knowledge of the species $(8 \%)$, or because of taxonomic adjustments (1\%). Once these non-genuine changes have been removed, the analysis shows a small decline in the RLI over time. This is because between 2009 and 2015 the genuine change in status for Amietia hymenopus moved from Least Concern (LC) to Near Threatened (NT). The change in status of this high altitude species was justified by observations of threats from chytrid infections, die-offs of tadpoles from drying of streams and severe freezing in winter, which may be associated with climate change.

Our analysis suggests that most threats to populations of South African frogs happened prior to 1990 (Table 6). However, change in habitat status between 1990 and 2004 did result in significant losses for species in the Western Cape, Eastern Cape and KwaZulu-Natal (Jewitt 2012) provinces - areas that also encapsulate the highest diversity and numbers of endemic frogs in South Africa (Poynton 1964; Schreiner et al. 2013).

\section{Conclusion}

\section{Should we continue to prioritise amphibian conservation research in South Africa?}

Our results suggest that the prioritisation of conservation research was a great success in terms of increased taxonomic understanding, generating distribution data, research publications, number of graduating students and improved public awareness. Although we used a scoring process to rank priorities, we did not find that species that had received a higher priority ranking were more likely to receive research attention. This could be not only because participants already had research projects on certain taxa, but also because many of the taxa were related to the distribution of herpetologists and the ease of conducting fieldwork.

This then raises the question of what should happen to species that received a high priority, but where no research has actually been conducted? For taxonomy, there is a level at which, excluding major revisions, species groups can be removed from the priority list. For conservation and monitoring, we feel that the original list still has validity, but that all lists could and should be shorter to reflect the reality of a very small capacity in South Africa for conducting conservation research.

South Africa has two areas of frog endemicity (Poynton 1964) that correspond to two clear areas of activity in conservation research: KwaZulu-Natal and the Western Cape provinces. Priorities continue to exist outside of these areas, but with a severely limited capacity to conduct research. The Northern Cape province has several species of conservation importance, but without any current capacity to carry out conservation research. This is certainly worrying, but our best hope is to continue to train and graduate students who have a focus on amphibian conservation, motivate for improved funding support for amphibian conservation from both national and international sources, and to educate and sensitise the general public to the need for frog conservation in South Africa.

A new strategy for conservation research will be formulated at a workshop in 2019. Lessons learned from the 2009 strategy will be carried forward. We plan to prioritise fewer target taxa, emphasise the potential for Citizen Science input and continue to explore ways of building capacity for conservation research on South Africa's amphibians.

\section{Acknowledgements}

The authors would like to thank Francois Becker, Marius Burger, Alan Channing, James Harvey, Les Minter, Domatilla Raimondo, Krystal Tolley and Atherton de Villiers who all made helpful comments on a previous version of this article. J.M., A.R. and M.M. would like to thank the DST-NRF Centre of Excellence for Invasion Biology for support.

\section{Competing interests}

The authors declare that they have no financial or personal relationships that may have inappropriately influenced them in writing this article.

\section{Authors' contributions}

J.M., J.T., A.T. and L.D.P. wrote the boxes. J.M., J.T., A.T. and M.M. conducted the Red List Index for South African amphibians. W.C. and A.R. had oversight of the distribution data and taxonomy. J.M. drafted the article. All authors attended the workshop and reviewed versions of the article.

\section{Ethical considerations}

No ethical clearance was required for this study. This article followed all ethical standards for research without direct contact with human or animal subjects. 


\section{Funding}

Both workshops were carried out with support from SANBI (NORAD).

\section{Data availability statement}

Data sharing is not applicable to this article as no new data were created or analysed in this study.

\section{Disclaimer}

The views and opinions expressed in this article are those of the authors and do not necessarily reflect the official policy or position of any affiliated agency of the authors.

\section{References}

Armstrong, A.J. \& Tarrant, J., 2017, 'Biodiversity management plan for Hyperolius pickersgilli', National Department of Environmental Affairs, National Environmental Management: Biodiversity Act 10 of 2004, Government Notice No. 423 in Government Gazette 40883 of 20 June 2017, Government of South Africa, Pretoria.

Becker, F.S., 2017, 'Searching for answers to the silent decline: First estimates of survival and recruitment for the critically endangered Rose's mountain toadlet, Capensibufo rosei', MSc thesis, University of Cape Town, viewed 21 December 2018, from http://hdl.handle.net/11427/12721.

Becker, F.S., Tolley, K.A., Measey, G.J. \& Altwegg, R., 2018, 'Extreme climate-induced life-history plasticity in an amphibian', The American Naturalist 191(2), 250-258. https://doi.org/10.1086/695315

Bell, K.J., 2009, 'The distribution of the desert rain frog (Breviceps macrops) in South Africa', MSc thesis, University of the Western Cape, viewed 21 December South Africa', MSc thesis, University of the Western Cape
2018, from https://etd.uwc.ac.za/handle/11394/3135.

Botha, V., 2014, 'Eco-morphological guilds and diet of exotrophic anuran tadpoles', MSc thesis, North-West University. http://hdl.handle.net/10394/12236

Botts, E.A., 2013, 'Distribution change in South African frogs', PhD thesis, University of the Witwatersrand, viewed 21 December 2018, from http://hdl.handle. net/10539/12368.

Botts, E.A., Erasmus, B.F. \& Alexander, G.J., 2011, 'Geographic sampling bias in the South African Frog Atlas Project: Implications for conservation planning', Biodiversity and Conservation 20(1), 119-139.

Botts, E.A., Erasmus, B.F. \& Alexander, G.J., 2013, 'Small range size and narrow niche breadth predict range contractions in South African frogs', Global Ecology and Biogeography 22(5), 567-576. https://doi.org/10.1111/geb.12027

Botts, E.A., Erasmus, B.F. \& Alexander, G.J., 2015, 'Observed range dynamics of South African amphibians under conditions of global change', Austral Ecology 40(3), 309-317. https://doi.org/10.1111/aec.12215

Blaustein, A.R. \& Wake, D.B., 1990, 'Declining amphibian populations: A global phenomenon?' Trends in Ecology and Evolution 5(7), 203-204. https://doi. org/10.1016/0169-5347(90)90129-2

Brooks, T.M., Mittermeier, R.A., Da Fonseca, G.A., Gerlach, J., Hoffmann, M., Lamoreux, J.F. et al., 2006, 'Global biodiversity conservation priorities', Science 313(5783), 58-61. https://doi.org/10.1126/science.1127609

Brown, L., 2015, 'Aspects of the breeding behaviour of Queckett's river frog (Amietia quecketti)', MSc Thesis. North-West University. http://hdl.handle.net/10394/14468

Bubb, P.J., Butchart, S.H.M., Collen, B., Dublin, H., Kapos, V., Pollock, C. et al., 2009 IUCN Red List index - Guidance for national and regional use, IUCN, Gland.

Butchart, S.H., Akçakaya, H.R., Chanson, J., Baillie, J.E., Collen, B., Quader, S. et al., 2007, 'Improvements to the red list index', PLoS One 2(1), e140. https://doi. org/10.1371/journal.pone.0000140

Carruthers, V.C. \& Du Preez, L.H., 2011a, Paddas en Paddajolyt, 108 pp, Struik Nature, Kaapstad.

Carruthers, V.C. \& Du Preez, L.H., 2011b, Frogs and frogging in South Africa, 108 pp Struik Nature, Kaapstad.

Channing, A., 2001, Amphibians of central and southern Africa, Comstock Pub. Associates, Ithaca, NY.

Channing, A., 2012, 'A new species of rain frog from Namaqualand, South Africa (Anura: Brevicipitidae: Breviceps)', Zootaxa 3381(1), 62-68. https://doi. org/10.11646/zootaxa.3381.1.4

Channing, A. \& Baptista, N., 2013. 'Amietia angolensis and A. fuscigula (Anura: Pyxicephalidae) in southern Africa: A cold case reheated', Zootaxa 3640(4), 501-520. https://doi.org/10.11646/zootaxa.3640.4.1

Channing, A., Dehling, J.M., Lötters, S. \& Ernst, R., 2016, 'Species boundaries and taxonomy of the African river frogs (Amphibia: Pyxicephalidae: Amietia)', Zootaxa 4155(1), 1-76. https://doi.org/10.11646/zootaxa.4155.1.1

Channing, A., Measey, G.J., Minter, L. \& Harvey, J., 2011, 'Understanding and documenting species diversity', G.J. Measey (ed.), Ensuring a future for South Africa's frogs: A strategy for conservation research, SANBI Biodiversity Series, pp. 12-17, SANBI, Pretoria.
Channing, A., Measey, G.J., Villiers, A.L., Turner, A.A. \& Tolley, K.A., 2017, 'Taxonomy of the Capensibufo rosei group (Anura: Bufonidae) from South Africa', Zootaxa 4232(2), 282-292. https://doi.org/10.11646/zootaxa.4232.2.11

Channing, A. \& Rödel, M.-O., 2019, Field guide to the frogs and other amphibians of Africa, 408 pp., Struik Nature, Cape Town.

Channing, A., Rödel, M.O. \& Channing, J., 2012, Tadpoles of Africa: The biology and identification of all known tadpoles in sub-Saharan Africa, vol. 55, 404 pp, Chimera, Frankfurt.

Channing, A., Schmitz, A., Burger, M. \& Kielgast, J., 2013, 'A molecular phylogeny of African Dainty Frogs, with the description of four new species (Anura: Pyxicephalidae: Cacosternum)', Zootaxa 3701(5), 518-550. http://doi.org/ 10.11646/zootaxa.3701.5.2

Coetzee, R., 2018, 'Influence of the invasive fish, Gambusia affinis, on amphibians in the Western Cape', MSc thesis, North-West University. http://hdl.handle. net/10394/27509

Colville, J.F., Potts, A.J., Bradshaw, P.L., Measey, G.J., Snijman, D., Picker, M.D. et al., 2014, 'Floristic and faunal Cape biochoria: Do they exist?', in N. Allsopp, J.F. Colville, G.A. Verboom (eds.), Fynbos: Ecology, evolution and conservation of a megadiverse region, pp. 73-93, Oxford University Press.

Conlon, J.M., Mechkarska, M., Coquet, L., Leprince, J., Jouenne, T., Vaudry, H. et al., 2015, 'Evidence from peptidomic analysis of skin secretions that allopatric populations of Xenopus gilli (Anura: Pipidae) constitute distinct lineages', Peptides 63, 118-125. https://doi.org/10.1016/j.peptides.2014.11.005

Conradie, W., 2014, 'The king of the dwarves: A new cryptic species of Dainty Frog (Anura: Pyxicephalidae: Cacosternum) from the eastern Great Escarpment of South Africa', Zootaxa 3785(3), 438-452. https://doi.org/10.11646/zootaxa. 3785.3.6

Conradie, B., Treurnicht, M., Esler, K. \& Gaertner, M., 2013, 'Conservation begins after breakfast: The relative importance of opportunity cost and identity in shapin private landholder participation in conservation', Biological Conservation 158, 334-341. https://doi.org/10.1016/j.biocon.2012.08.028

Conradie, W. \& Tarrant, J., 2011, 'Amatola toad AWOL: Thirteen years of futile searches', Froglog $97,24$.

Cressey, E.R., 2012, 'The conservation genetics of a newly recognised Cape Peninsula endemic Rose's Mountain toad (Capensibufo rosei)', viewed 21 December 2018 from http://hdl.handle.net/11427/12086.

Cressey, E.R., Measey, G.J. \& Tolley, K.A., 2015, 'Fading out of view: The enigmatic decline of Rose's mountain toad Capensibufo rosei', Oryx 49(3), 521-528. https:// doi.org/10.1017/S0030605313001051

Da Silva, J.M., Feldheim, K.A., Daniels, R.J., Edwards, S. \& Tolley, K.A., 2016, 'Analysis of genetic diversity in Rose's mountain toadlet (Capensibufo rosei) using novel microsatellite markers', African Journal of Herpetology 65(2), 69-82. https://doi. org/10.1080/21564574.2016.1234511

Da Silva, J.M., Feldheim, K.A., Measey, G.J., Doucette-Riise, S., Daniels, R.J, Chauke, L.F. et al., 2017, 'Genetic diversity and differentiation of the Western Leopard Toad (Sclerophrys pantherina) based on mitochondrial and microsatellite Leopard Toad (Sclerophrys pantherina) based on mitochondrial and microsatellite markers', African Journ

Da Silva, J.M \& Tolley K.A. 2018 ,Conservation genetics of an endemic and threatened amphibian (Capensibufo rosei): A leap towards establishing a genetic monitoring framework', Conservation Genetics 19(2), 349-363. https://doi. monitoring framework', Conservati
org/10.1007/s10592-017-1008-9

Davies, S.J., 2014, 'Geographic range, spread and potential distribution of the painted reed frog Hyperolius marmoratus in the Western Cape Province, South Africa', PhD thesis, Stellenbosch University', viewed 21 December 2018, from http://hdl. $\mathrm{PhD}$ thesis, Stellenbosch Unive
handle.net/10019.1/95747.

e Jongh, M., 2015, 'Efficacy of F10 against amphibian chytrid fungus', MSc thesis, North-West University. http://hdl.handle.net/10394/15171

De Villiers, A.L., 2004, 'Capensibufo rosei (Hewitt, 1926)', in L.R. Minter, M. Burger, J.A. Harrison, H.H. Braack, P.J. Bishop \& D. Kloepfer (eds.), Atlas and red data book of the frogs of South Africa, Lesotho and Swaziland, pp. 87-90, Smithsonian Institution, Washington, DC.

De Villiers, F.A., 2016, 'The dispersal ability, performance and population dynamics of Cape Xenopus frogs', MSc thesis, Stellenbosch University, viewed 21 December 2018, from http://hdl.handle.net/10019.1/98350.

De Villiers, F.A., De Kock, M. \& Measey, G.J., 2016, 'Controlling the African clawed frog Xenopus laevis to conserve the Cape platanna Xenopus gilli in South Africa', Conservation Evidence 13, 17.

De Villiers, F.A. \& Measey, J., 2017, 'Overland movement in African clawed frogs (Xenopus laevis): Empirical dispersal data from within their native range', PeerJournal 5, e4039. https://doi.org/10.7717/peerj.4039

Dorcas, M.E., Price, S.J., Walls, S.C. \& Barichivich, W.J., 2009, 'Auditory monitoring of anuran populations', in C.K. Dodd (ed.), Amphibian ecology and conservation: A hand book of techniques (pp. 281- 298), Oxford University Press, Oxford.

Doucette-Riise, S., 2012, 'Migration and dispersal of the western leopard toad (Amietophrynus pantherinus) in a fragmented agricultural landscape', MSc thesis, University of Cape Town, viewed 21 December 2018, from http://hdl.handle. net/11427/10420.

Drinkrow, D.R. \& Cherry, M.I., 1995, 'Anuran distribution, diversity and conservation in South Africa, Lesotho and Swaziland', African Zoology 30(3), 82-90. https://doi org/10.1080/02541858.1995.11448376

Du Pissanie, A., 2015, 'The effect of glyphosate and Cry1Ab proteins on the growth and survival of tadpoles of two amphibian species', MSc thesis, North-West University. http://hdl.handle.net/10394/17250 
Du Preez, Z., 2018, 'Ecotourism potential of frogs in South Africa', MSc thesis, North-West University. http://hdl.handle.net/10394/31240

Du Preez, L.H. \& Carruthers, V.C., 2009, Frogs of Southern Africa: A complete guide, Struik Nature, Cape Town.

Du Preez, L.H. \& Carruthers, V.C., 2017, Frogs of Southern Africa: A complete guide, Penguin Random House, Cape Town.

Edwards, S., Tolley, K.A. \& Measey, G.J., 2017, 'Habitat characteristics influence the breeding of Rose's dwarf mountain toadlet Capensibufo rosei (Anura: Bufonidae)', Herpetological Journal 27(3), 287-298.

Fogell, D.J., Tolley, K.A. \& Measey, G.J., 2013, 'Mind the gaps: Investigating the cause of the current range disjunction in the Cape Platanna, Xenopus gilli (Anura: Pipidae)', PeerJournal 1, e166. https://doi.org/10.7717/peerj.166

Furman, B.L., Cauret, C.M., Colby, G.A., Measey, G.J. \& Evans, B.J., 2017, 'Limited genomic consequences of hybridization between two African clawed frogs, Xenopus gilli and X. laevis (Anura: Pipidae)', Scientific Reports 7(1), 1091. https:// Xenopus gilli and X. laevis (Anura: Pipidae
doi.org/10.1038/s41598-017-01104-9

GeoTerralmage, 2015, 'Technical report: 2013/2014 South African National Land Cover Dataset version 5', viewed 21 December 2017, from http://egis.environment.gov.za.

GeoTerralmage, 2016, 'Technical report: 1990 South African National Land Cove Dataset version 5.2', viewed 21 December 2017, from http://egis.environment. gov.za.

Gericke, M.C., 2009, 'Aspects of amphibian chytrid infections in South Africa', MSc thesis, North-West University. http://hdl.handle.net/10394/3713

Harrison, J.A., Burger, M., Minter, L.R., De Villiers, A.L., Baard, E.H.W., Scott, E. et al. 2001, Conservation assessment and management plan for southern African frogs, World Conservation Union/Species Survival Commission Conservation Breedin Specialist Group, Apple Valley, MN

IUCN, 2017, The IUCN red list of threatened species, Version 2017-1, viewed 21 December 2017, from http://www.iucnredlist.org.

Jewitt, D., 2012, 'Land cover change in KwaZulu-Natal', Environment 10, 12-13.

Köhler, J., Vieites, D.R., Bonett, R.M., García, F.H., Glaw, F., Steinke, D. et al., 2005 New amphibians and global conservation: A boost in species discoveries in highly endangered vertebrate group', Bioscience 55(8), 693-696. https://doi. org/10.1641/0006-3568(2005)055[0693:NAAGCA]2.0.CO;2

Kruger, D.J.D., 2011, 'Tadpole morphology of high altitude frogs from the Drakensberg mountains', M. Env. Sci. MSc thesis, North-West University. http://hdl.handle. net/10394/4464

Kruger, D.J.D., 2014, 'Frogs about town: Aspects of the ecology and conservation of frogs in urban habitats of South Africa', PhD thesis, North-West University. http:// hdl.handle.net/10394/15346

Kruger, N., 2017, 'Parasite introduction to the Endangered western leopard toad: Spill over or spill back?' MSc thesis, North-West University. http://hdl handle. Spill over or spill
net/10394/25435

Kushata, J.N.T., 2018, 'Comparative phylogeography of three anuran species in the Eastern Cape Province forests, South Africa', MSc thesis, Stellenbosch University viewed 21 December 2018, from http://hdl.handle.net/10019.1/104838.

Louw, M., 2018, 'Acoustic Spatial Capture-Recapture (aSCR) and the Cryptic Cape Peninsula Moss Frog Arthroleptella lightfooti', MSc thesis, Stellenbosch University, viewed 21 December 2018, from http://hdl.handle.net/10019/21746.

Matthew, E., 2016, 'The use of a sniffer dog for amphibian conservation ecology', MSc thesis, North-West University. http://hdl.handle.net/10394/18954

Measey, G.J., 2011, Ensuring a future for South Africa's frogs: A strategy for conservation research, SANBI Biodiversity Series, SANBI, Pretoria.

Measey, G.J., Weldon, C., Morgan, D., Channing, A., Harvey, J. \& Turner, A., 2011 'Conservation and ecological studies', in G.J. Measey (ed.), Ensuring a future for South Africa's frogs: A strategy for conservation research, SANBI Biodiversity Series, p. 18, SANBI, Pretoria.

Measey, G.J., Minter, L.R. \& Turner, A., 2011, 'Assessing status and trends', in G.J. Measey, Ensuring a future for South Africa's frogs: A strategy for conservation research, SANBI Biodiversity Series, p. 29, SANBI, Pretoria.

Measey, J., Dorse, S. \& Faraday, A., 2012, 'Conservation of the Western Leopard Toad by a dedicated multi-stakeholder group in the city of Cape Town', FrogLog 103, 14-16.

Measey, G.J. \& De Villiers, A., 2011, 'Conservation introduction of the Cape Platanna within the Western Cape, South Africa', in P.S. Soorae, Global re-introduction Perspectives: 2011. More case studies from around the globe, pp. 91-93, IUCN/ SSC Re-introduction Specialist Group \& Environment Agency, Abu Dhabi.

Measey, G.J. \& Tolley, K.A., 2011a, 'Building a strategy for amphibian conservation through a workshop process', in G.J. Measey (eds.), Ensuring a future for South Africa's frogs: A strategy for conservation research, SANBI Biodiversity Series, p. 10, SANBI, Pretoria.

Measey, G.J. \& Tolley, K.A., 2011b, 'Investigating the cause of the disjunct distribution of Amietophrynus pantherinus, the Endangered South African western leopard toad" Conservation Genetics 12(1), 61-70. https://doi.org/10.1007/s10592-009-9989-7

Meyer, L., 2009, 'Seasonal variation and the influence of environmental gradients on Batrachochytrium dendrobatidis infections in frogs from the Drakensberg Mountains', MSc thesis, North-West University. http://hdl.handle.net/10394/5098

Minter, L.R., 2014, 'Aspects of the reproductive biology of Breviceps', PhD thesis. University of the Witwatersrand, viewed 21 December 2018, from http://hdl. handle.net/10539/15564.

Minter, L.R., Netherlands, E.C. \& Du Preez, L.H., 2017, ‘Uncovering a hidden diversity: Two new species of Breviceps (Anura: Brevicipitidae) from northern KwaZuluNatal, South Africa', Zootaxa 4300(2), 195-216. http://doi.org/10.11646/ zootaxa.4300.2.3
Minter, L.R., Burger, M., Harrison, J.A., Braack, H.H., Bishop, P.J. \& Knoepfer, D., 2004 Atlas and red data book of the frogs of South Africa, Lesotho and Swaziland, $\mathrm{SI}$ MAB Series No. 9, Smithsonian Institution Press, Washington, DC.

Mittermeier, R.A., Robles Gil, P., Hoffmann, M., Pilgrim, J., Brooks, T., Mittermeier, C.G., Lamoreux, J. et al., 2004, Hotspots revisited: Earth's biologically richest and most endangered ecoregions, CEMEX, Mexico.

Mokhatla, M.M., 2012, 'Biogeographical implications for amphibian conservation in southern Africa', MSc Thesis, University of Pretoria, viewed 21 December 2018, from http://hdl.handle.net/2263/19980

Mokhatla, M.M., 2018, 'Evaluating the effects of changing global climate on amphibian functional groups of southern Africa: An ecophysiology modelling approach PhD thesis, Stellenbosch University, viewed 21 December 2018, from http://hdl. handle.net/10019/21777.

Mokhatla, M.M., Measey, G.J., Chimimba, C.T. \& Van Rensburg, B.J., 2012, 'A biogeographical assessment of anthropogenic threats to areas where different frog breeding groups occur in South Africa: Implications for anuran conservation Diversity and Distributions 18(5), 470-480. https://doi.org/10.1111/j.1472 4642.2011.00870.x

Mokhatla, M.M., Rödder, D. \& Measey, G.J., 2015, 'Assessing the effects of climate change on distributions of Cape Floristic Region amphibians', South African Journal of Science 111(11-12), 1-7. https://doi.org/10.17159/sajs. 2015/20140389

Netherlands, E., 2015, 'Species diversity, habitat utilization and blood parasites of amphibians in and around Ndumo Game Reserve', MSc thesis, North-West University. http://hdl.handle.net/10394/15475

Nielsen, S.V., Daniels, S.R., Conradie, W., Heinicke, M.P. \& Noonan, B.P., 2018 'Multilocus phylogenetics in a widespread African anuran lineage (Brevicipitidae: Breviceps) reveals patterns of diversity reflecting geoclimatic change', Journal of Biogeography 45(9), 2067-2079. https://doi.org/10.1111/jbi.13394

Passmore, N.I. \& Carruthers, V.C., 1979, South African frogs, p. 270, Witwatersrand University Press, Johannesberg.

Phaka, F.M., Netherlands, E.C., Kruger, D.J.D. \& Du Preez, L.H., 2017, A bilingual field guide to the frogs of Zululand. Suricata 3, South African National Biodiversity Institute, Pretoria.

Phaka, M.F., 2018, 'Amphibian diversity and community-based ecotourism in Ndumo Game Reserve, South Africa', MSc thesis, North-West University. http://hdl. handle.net/10394/27893

Poynton, J.C., 1964, 'Amphibia of southern Africa: A faunal study', Annals of Nata Museum 17, 1-334.

Pretorius, A., 2017, 'Disease dynamics in a metapopulation of Amietia hymenopus', MSc thesis, North-West University. http://hdl.handle.net/10394/25153

Rebelo, A.D., 2017, 'Investigating the morphology, locomotory performance and macroecology of a sub-Saharan African frog radiation (Anura: Pyxicephalidae)' MSc thesis, Stellenbosch University, viewed 21 December 2018, from http://hdl. handle.net/10019.1/101468

Rouget, M., Barnett, M., Cowling, R.M., Cumming, T., Daniels, F., Hoffman, M.T. et al., 2014, Conserving the Cape Floristic Region, pp. 321-336, Oxford University Press, Oxford.

Rose, W., 1962, The reptiles and amphibians of Southern Africa, Maskew Miller, Cape Town

Ryan, T., 2015, 'Amphibian habitat requirements in Highveld Pans: Implications for conservation', MSc thesis, University of the Witwatersrand, viewed 21 December 2018, from http://hdl.handle.net/10539/18594.

Schreiner, C., Rödder, D. \& Measey, G.J., 2013, 'Using modern models to test Poynton's predictions', African Journal of Herpetology 62(1), 49-62. https://doi.org/10.108 $0 / 21564574.2013 .794865$

Stark, D., Turner, A., Van Rensburg, B.J. \& Measey, J., in press, 'Population estimation of a cryptic moss frog using acoustic spatially explicit capture recapture', in S.C. Walls \& K.M. O'Donnell (eds.), Strategies for conservation success in herpetology, Herpetological conservation series, vol. 4 , Society for the Study of herpetology, Herpetological conservation

Stevenson, B.C., Borchers, D.L., Altwegg, R., Swift, R.J., Gillespie, D.M. \& Measey, G.J. 2015 'A general framework for animal density estimation from acoustic detections across a fixed microphone array', Methods in Ecology and Evolution 6(1), 38-48.

Stuart, S.N., Chanson, J.S., Cox, N.A., Young, B.E., Rodrigues, A.S., Fischman, D.L. et al., 2004, 'Status and trends of amphibian declines and extinctions worldwide', Science 306(5702), 1783-1786. https://doi.org/10.1126/science.1103538

Tarrant, J., 2012, 'Conservation assessment of threatened frogs in KwaZulu-Natal and a national assessment of chytrid infection in threatened South African species', PhD thesis, North-West University. http://hdl.handle.net/10394/8490

Tarrant, J., 2015, My first book of Southern African frogs, Struik Nature, Cape Town, pp. 63, ISBN: 9781775841586.

Tarrant, J. \& Armstrong, A.J., 2013, 'Using predictive modelling to guide the conservation of a critically endangered coastal wetland amphibian Journal for Nature Conservation 21(5), 369-381. https://doi.org/10.1016/j jnc.2013.03.006

Tarrant, J. \& Cunningham, M.J., 2011, 'Rediscovery of the elusive Amatola Toad Vandjikophrynus amatolicus: Twice seen in twenty-six years', African Herp News 55, 1-6.

Tarrant, J., Kruger, D. \& Du Preez, L.H., 2016, ‘Do public attitudes affect conservation effort? Using a questionnaire-based survey to assess perceptions, beliefs and
superstitions associated with frogs in South Africa', African Zoology 51(1), 13-20. superstitions associated with frogs in South Africa',
https://doi.org/10.1080/15627020.2015.1122554 
Telford, N., 2015, 'The invasive guttural toad, Amietophrynus gutturalis', MSc thesis, University of the Western Cape, viewed 21 December 2018, from https://etd.uwc. ac.za/handle/11394/4867.

Thorp, C.J., 2017, 'The impact of Xenopus laevis predation on aquatic ecosystems', MSc thesis, Stellenbosch University, viewed 21 December 2018, from http://hdl. handle.net/10019.1/101481.

Thorp, C.J., Vonesh, J.R. \& Measey, J., 2019, 'Cannibalism or congeneric predation? The African clawed frog, Xenopus laevis (Daudin), preferentially predates on larvae of Cape platannas, Xenopus gilli Rose and Hewitt', African Journal of Ecology 57(1), 59-65. https://doi.org/10.1111/aje.12577

Tolley, K.A., De Villiers, A.L., Cherry, M.I. \& Measey, G.J., 2010, 'Isolation and high genetic diversity in dwarf mountain toads (Capensibufo) from South Africa', Biological Journal of the Linnean Society 100(4), 822-834.

Tolley, K.A., Minter, L., Harvey, J., Tarrant, J. \& Measey, G.J., 2011, 'Education, awareness and capacity building', in G.J. Measey (ed.), Ensuring a future for South Africa's Frogs: A strategy for conservation research, SANBI Biodiversity Series, p. 37, SANBI, Pretoria.

Tolley, K.A., Conradie, W., Harvey, J., Measey, J. \& Blackburn, D.C., 2018, 'Molecular phylogenetics reveals a complex history underlying cryptic diversity in the Bush Squeaker Frog (Arthroleptis wahlbergii) in southern Africa', African Zoology 53(3), 83-97. https://doi.org/10.1080/15627020.2018.1517608

Trenor, M., 2017, 'Saving South Africa's endangered Mistbelt Chirping Frog (Anhydrophryne ngongoniensis)', MSc thesis, North-West University. http://hdl. handle.net/10394/31302

Turner, A.A., 2009, 'Phylogeography and speciation in the genus Arthroleptella', PhD thesis, University of the Western Cape, viewed 21 December 2018, from https:// etd.uwc.ac.za/handle/11394/3434.
Turner, A. \& Channing, A., 2017, 'Three new species of Arthroleptella Hewitt, 1926 (Anura: Pyxicephalidae) from the Cape Fold Mountains, South Africa', African Journal of Herpetology 66(1), 53-78. https://doi.org/10.1080/21564574.2017.1324918

Verster, J.R., 2018, 'Spatial epidemiology of amphibian chytridiomycosis in the Orange Rivers system of South Africa', MSc thesis, North-West University. http://hdl. handle.net/10394/31314

Vimercatti, G., 2017, 'Exploring the invasion of the guttural toad Sclerophrys gutturalis in Cape Town through a multidisciplinary approach', PhD thesis, Stellenbosch University, viewed 21 December 2018, from http://hdl.handle. net/10019.1/101379.

Viviers, J., 2013, 'Seasonal migration and reproductive behaviour of the Common River Frog (Amietia quecketti)', MSc thesis, North-West University. http://hdl. handle.net/10394/10212

Vogt, S., De Villiers, F.A., Ihlow, F., Rödder, D. \& Measey, J., 2017, 'Competition and feeding ecology in two sympatric Xenopus species (Anura: Pipidae)', PeerJournal 5, e3130. https://doi.org/10.7717/peerj.3130/table-1

Wager, V.A., 1965, The frogs of South Africa, Purnell, Cape Town.

Wison, L., 2015, 'Genetic analysis of the Cape Sand Frog, Tomopterna delalandi (Tschudi 1838)', M.Sc thesis, University of the Western Cape, viewed 21 December 2018, from http://etd.uwc.ac.za/handle/11394/4866.

Wolmarans, N.J., 2016, 'The relationship between organochlorine pesticide exposure and biomarker responses of amphibians in the lower Phongolo River floodplain', MSc thesis, North-West University. http://hdl.handle.net/10394/15824

Zaayman, J.L., 2013, 'Bt maize and frogs: An investigation into possible adverse effects of Bt toxin exposure to amphibian larvae', MSc thesis, North-West University. http://hdl.handle.net/10394/9869 